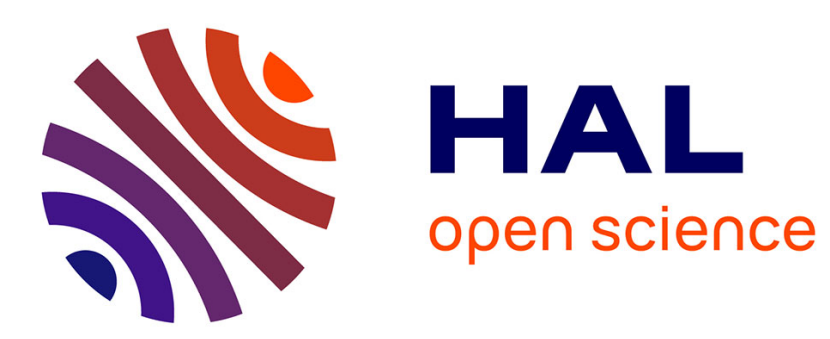

\title{
Molting as a mechanism of depuration of metals in the fiddler crab,
}

\author{
Lauren L. Bergey, Judith S. Weis
}

\section{To cite this version:}

Lauren L. Bergey, Judith S. Weis. Molting as a mechanism of depuration of metals in the fiddler crab,. Marine Environmental Research, 2007, 64 (5), pp.556. 10.1016/j.marenvres.2007.04.009 . hal00562981

\section{HAL Id: hal-00562981 \\ https://hal.science/hal-00562981}

Submitted on 4 Feb 2011

HAL is a multi-disciplinary open access archive for the deposit and dissemination of scientific research documents, whether they are published or not. The documents may come from teaching and research institutions in France or abroad, or from public or private research centers.
L'archive ouverte pluridisciplinaire HAL, est destinée au dépôt et à la diffusion de documents scientifiques de niveau recherche, publiés ou non, émanant des établissements d'enseignement et de recherche français ou étrangers, des laboratoires publics ou privés. 


\section{Accepted Manuscript}

Molting as a mechanism of depuration of metals in the fiddler crab, Uca pugnax

Lauren L. Bergey, Judith S. Weis

PII:

S0141-1136(07)00071-2

DOI:

10.1016/j.marenvres.2007.04.009

Reference:

MERE 3124

To appear in:

Marine Environmental Research

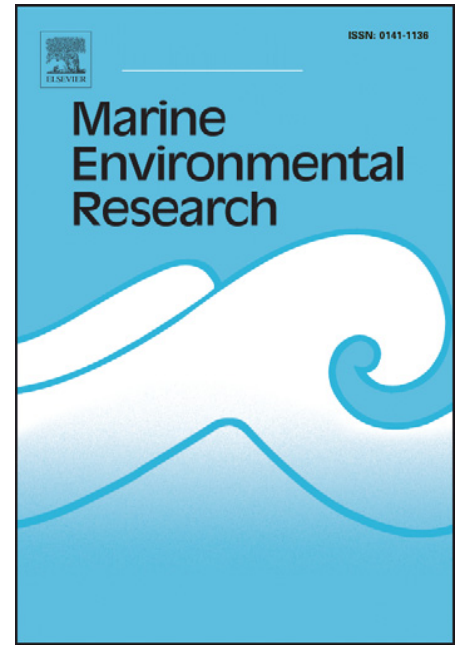

Received Date:

8 March 2007

Revised Date:

26 April 2007

Accepted Date:

28 April 2007

Please cite this article as: Bergey, L.L., Weis, J.S., Molting as a mechanism of depuration of metals in the fiddler crab, Uca pugnax, Marine Environmental Research (2007), doi: 10.1016/j.marenvres.2007.04.009

This is a PDF file of an unedited manuscript that has been accepted for publication. As a service to our customers we are providing this early version of the manuscript. The manuscript will undergo copyediting, typesetting, and review of the resulting proof before it is published in its final form. Please note that during the production process errors may be discovered which could affect the content, and all legal disclaimers that apply to the journal pertain. 


\section{MOLTING AS A MECHANISM OF DEPURATION OF METALS IN THE FIDDLER CRAB, Uca pugnax.}

Lauren L. Bergey and Judith S. Weis

Rutgers, The State University of New Jersey

Department of Biological Sciences

195 University Ave.

Newark, NJ 07102, USA

Lauren Bergey

$\underline{\text { lbergey@pegasus.rutgers.edu }}$

Phone: (973) 353-1316

Fax: (973) 353-5518 
Introduction

The Atlantic marsh fiddler crab, Uca pugnax, is the most abundant of its genus on the eastern coast of the United States. From Cape Cod to Florida, they inhabit intertidal salt marshes in sheltered bays and estuaries and fill a major niche in these ecosystems. $U$. pugnax is a food source for a variety of organisms including birds, fish, and other crabs (Crane, 1975). In addition, their burrowing behavior stimulates the turnover of nutrients in the marsh sediment, aerates the soil, and allows deeper root penetration of marsh plants (Bertness, 1985).

Crustaceans have an exoskeleton that must be shed in order to grow. During proecdysis a new cuticle is produced underneath the old one, which is subsequently shed (ecdysis). Calcium is reabsorbed from the exoskeleton just prior to molting, which softens the carapace so that it can be shed (Greenaway, 1985). After ecdysis has occurred, the stored calcium is utilized to harden the new cuticle.

Metals such as copper, lead, and zinc are commonly found in estuaries surrounding urban environments. Metals can be bound to chitin in exoskeletons of crustaceans (Keteles and Fleeger, 2001). These metals become associated with the calcium in the exoskeleton matrix. They may be absorbed to the surface of the exoskeleton or bind to the inner exoskeleton matrix after uptake (Keteles and Fleeger, 2001). Metals also accumulate in the hepatopancreas, and can be stored in granules and/or by binding to metallothioneins (Carvalho and Fowler, 1993; Wallace et al., 2000). Metal-rich granules are a mechanism for long term storage of essential and non essential metals, where as binding to metallothioneins, regulates internal metal concentrations on shorter time scales (Brown, 1982; Roesijadi, 1992). 
Metals can cause disruption of molting, limb regeneration, alteration of blood glucose levels, color changes, and impairment of reproduction in crustaceans (Defur et al., 1999). Elumalai et al, (2004) found that exposure to cadmium and chromium can alter the reproductive cycle of $C$. maenas, and that the combination of the two metals disrupted the reproductive cycle to a greater extent. Metals have been shown to inhibit regeneration and molting in fiddler crabs (Callahan and Weis, 1983 and Weis et al., 1992). Mercury can also cause sluggishness and lack of responsiveness as well as premature egg dropping in females (Vernberg and Vernberg, 1974). As larvae develop, their sensitivity to mercury increases and their swimming behavior is further altered (Vernberg and Vernberg, 1974). Vernberg and Vernberg (1974) found that sublethal exposure to cadmium affects the development of the larvae and alters their metabolic rate. There has also been some evidence that fiddler crabs may adapt to chronic exposure to toxicants and become more resistant. This could potentially impact the rest of the ecosystem as the toxicants move up the food chain (Callahan and Weis, 1983).

Since some fraction of the body burden of metals is associated with the exoskeleton, molting may be a way for arthropods to depurate metals. Molting in insects has been shown to reduce body burdens of heavy metals (Raessler et al, 2005). However, in the estuarine grass shrimp, Palaemonetes pugio, molting did not substantially reduce the amounts of copper, zinc, and cadmium, because they were reabsorbed with the calcium during proecdysis (Keteles and Fleeger, 2001). Bondgaard and Bjerregarrd (2005) found that molting of the crab Carcinus maenas did not reduce cadmium levels. Molting played a role in metal concentrations and their distributions in soft tissues and the exoskeleton in amphipods (Weeks et al, 1992). 
The purpose of the present study was to determine if fiddler crabs can reduce their overall body burdens of metals significantly as a result of molting. We studied two populations, one from a highly contaminated site and one from a relatively clean environment to determine if there were differences in the way copper, lead, and zinc were distributed in intermolt and postmolt individuals.

\section{Study Sites}

\section{$\underline{\text { Piles Creek (PC) }}$}

Piles Creek (PC) is located in Linden, New Jersey, and is a tributary of the Arthur Kill. The site is surrounded by industrial sites, a sewage treatment plant, and a major highway. Oil spills in the Arthur Kill and possible leachate from landfills have also been a source of organic contaminants (Perez and Wallace, 2004). This site has been the source of ecological research for over 20 years. Studies have been conducted on resident fish, shrimp, crabs, and ecology of the system (Santiago Bass et al., 2001). Elevated levels of organic contaminants and metals have been found in sediments and biota (Weis, et al., 2001).

\section{Great Bay-Mullica River Estuary (TK)}

The Tuckerton (TK) site is part of the Great Bay-Mullica River Estuary and part of the Jacques Cousteau National Estuarine Research Reserve in New Jersey. It is part of 3,500 acres of protected salt marsh. It is a non-industrialized site that is relatively clean and has also been monitored for many years of research (Santiago Bass et al., 2001). 
Materials and Methods

Intermolt Crabs

Eighteen male intermolt crabs from each population were collected and preserved on ice in August 2006. Analysis of metals (lead, copper, and zinc) was performed at the University of Medicine and Dentistry of New Jersey. Crabs were dissected and separated into the soft tissues (including hypodermis) and the carapace. The soft tissue samples and carapaces were dried and put through a series of acid digestions. $\mathrm{Cu}, \mathrm{Pb}$, and $\mathrm{Zn}$ were analyzed by using a flame aspiration AAS in a Perkin-Elmer 603 Atomic Absorption Spectrophotometer. Dolt 2, dogfish liver was used as a standard reference material for all analyses.

\section{Postmolt Crabs}

Male crabs from both locations were collected and brought back to the lab in August 2006. Molting was accelerated by multiple autotomy, which was induced by pinching the merus of the crabs' legs with forceps (Skinner and Graham, 1972). Two of the walking legs on each side of the crab and the large claw were removed. The crabs were then placed in individual containers with their native sediments and $18 \mathrm{ppt}$ artificial seawater at a depth that just covered the crab. Crabs were maintained at room temperature with a 14/10 light cycle, and monitored until they molted. Water was changed daily and sediment was changed every three days. Immediately after molting, both the soft crab and its exuvium (molt) were frozen for metal analysis. Initially 25 crabs from each population were used. All 25 PC crabs and exuvia were viable but only 20 viable TK crabs and exuviae were collected. Each newly molted soft crab and 
exuvium was dried and put through a series of acid digestions. Samples were analyzed for $\mathrm{Cu}, \mathrm{Pb}$, and $\mathrm{Zn}$ by using a flame aspiration $\mathrm{AAS}$ in a Perkin-Elmer 603 Atomic Absorption Spectrophotometer. Dolt 2, dogfish liver was used as a standard reference material for all analyses. Standard reference material recovery ranged from $92.3 \%$ to 104.5\%. A Wilcoxon Rank Sum Test was performed on the concentrations $(\mu \mathrm{g} / \mathrm{g})$ of each metal in the soft tissues and exuvia. An independent two sample t-test was performed on distributions of total body burden $(\mu \mathrm{g})$ of each of the metals in the soft tissues and exoskeletons.

\section{Results}

Intermolt Crabs

Concentrations $(\mu \mathrm{g} / \mathrm{g})$ and proportions (ratios calculated from whole body burdens) of copper, lead, and zinc in the carapace and soft tissues during intermolt of the two populations are presented in Table 1. Both populations had significantly higher concentrations of $\mathrm{Cu}$ in their soft tissues than carapace (PC $\mathrm{p}<0.001$; TK p $<0.001)$. The intermolt phase PC crabs had significantly higher concentrations of copper in their soft tissues $(p=0.003)$ than their conspecifics from TK. However, there was no significant difference in concentrations $(\mu \mathrm{g} / \mathrm{g})$ of copper in the carapaces $(\mathrm{p}=0.235)$. More copper was stored in the soft tissue than the carapace for both populations (PC 5.98:1 ratio; TK 2.26:1 ratio). However, PC crabs stored proportionally more copper in their soft tissues $(t(34)=2.04, \mathrm{p}=0.049)$ than their TK conspecifics.

Lead concentrations $(\mu \mathrm{g} / \mathrm{g})$ were not significantly different between soft tissue and carapace for PC $(\mathrm{p}=0.728)$. However, significantly higher concentrations were 
found in the carapace than soft tissues for TK $(\mathrm{p}=0.038)$. PC crabs also had significantly higher concentrations $(\mu \mathrm{g} / \mathrm{g})$ of lead in both their soft tissues $(\mathrm{p}=0.011)$ and their carapace $(\mathrm{p}=0.003)$ than TK crabs. Slightly more $\mathrm{Pb}$ was stored in the carapace than the soft tissues during intermolt for both populations, PC (1:0.81 ratio); TK (1:0.39 ratio). However, TK crabs stored proportionally more lead in their soft tissues $(t(34)=$ 3.27, $\mathrm{p}=0.003)$ than their PC conspecifics.

Zinc concentrations $(\mu \mathrm{g} / \mathrm{g})$ were significantly higher in soft tissues than carapace for both populations (PC $\mathrm{p}<0.001$; TK $\mathrm{p}<0.001)$. There was no significant difference in the concentrations $(\mu \mathrm{g} / \mathrm{g})$ of $\mathrm{Zn}$ the soft tissues $(\mathrm{p}=0.517)$ and carapaces $(\mathrm{p}=0.825)$ between populations. More $\mathrm{Zn}$ was stored in the soft tissues for both populations (PC 5.37:1 ratio, TK 1.94:1 ratio). There was also no significant difference $(t(34)=1.46, \mathrm{p}=$ $0.155)$ in proportions of $\mathrm{Zn}$ stored in the soft tissues between populations.

Postmolt crabs

Both PC and TK crabs had significantly higher concentrations of $\mathrm{Cu}(\mu \mathrm{g} / \mathrm{g})$ in the soft crab than the exuvium $(\mathrm{PC}<0.001$; $\mathrm{TK}<0.001)$. Concentrations $(\mu \mathrm{g} / \mathrm{g})$ and proportions (ratios) of copper, lead, and zinc burden in the soft crab and exuvium immediately after molting are presented in Table 2. Significantly higher concentrations $(\mu \mathrm{g} / \mathrm{g})$ of $\mathrm{Cu}$ were found in the PC soft crabs $(\mathrm{p}<0.001)$ and exuvia $(\mathrm{p}<0.001)$ than TK crabs. More copper was stored in the soft crab than the exuvia for both populations (PC 9.97:1 ratio, TK 46.66:1 ratio). TK crabs stored proportionally more copper in their soft tissues $(t(43)=5.27, \mathrm{p}<0.001)$ than their PC conspecifics.

Both PC and TK crabs had significantly higher concentrations of $\mathrm{Pb}(\mu \mathrm{g} / \mathrm{g})$ in the exuvia than the soft tissues $(\mathrm{PC}<0.001 ; \mathrm{TK}<0.001)$. Significantly higher 
concentrations $(\mu \mathrm{g} / \mathrm{g})$ of $\mathrm{Pb}$ were found in the soft crab $(\mathrm{p}<0.001)$ and the exuvia $(\mathrm{p}<$ 0.001) in the PC crabs than TK crabs. Post molt soft crabs contained more Pb than the exuvia in both populations ( $\mathrm{PC}$ 1:0.33 ratio, TK 1:0.84 ratio). PC crabs stored proportionally more lead in their soft tissues $(t(43)=8.36, \mathrm{p}<0.001)$ than their TK conspecifics.

Both populations had significantly higher concentrations of $\mathrm{Zn}(\mu \mathrm{g} / \mathrm{g})$ in the soft tissues than the exuvia $(\mathrm{PC}<0.001$; TK $<0.001)$. PC crabs had significantly higher concentrations $(\mu \mathrm{g} / \mathrm{g})$ of $\mathrm{Zn}$ in the soft crab $(\mathrm{p}=0.002)$ and exuvia $(\mathrm{p}<0.001)$ than TK crabs. More $\mathrm{Zn}$ was stored in the soft crab than the exuvia for both populations (PC 4.39:1 ratio, TK 14.47:1 ratio). PC crabs stored proportionally more zinc in their soft tissues $(t(43)=6.37, \mathrm{p}<0.001)$ than their TK conspecifics.

Crabs from both populations were able to reduce a large portion of their total body burden of lead as a result of molting (Figures 1 and 2). PC crabs shifted significant amounts of $\mathrm{Cu}(t(41)=5.41, \mathrm{p}<0.001)$ and $\mathrm{Zn}(t(41)=2.76, \mathrm{p}=0.009)$ into the soft tissue prior to molting. However, they shifted $\mathrm{Pb}(t(41)=4.89, \mathrm{p}<0.001)$ into the exoskeleton prior to molting. TK crabs shifted significant amounts of $\mathrm{Cu}(t(36)=16.55$, $\mathrm{p}<0.001), \mathrm{Pb}(t(36)=5.39, \mathrm{p}<0.001)$ and $\mathrm{Zn}(t(36)=15.56, \mathrm{p}<0.001)$ into the soft tissue prior to molting.

The average percent of the total body burden eliminated during intermolt for the contaminated PC crabs varied with each metal, $12 \% \mathrm{Cu}, 76 \% \mathrm{~Pb}$, and $22 \% \mathrm{Zn}$. The average percent of the total body burden eliminated during intermolt for the relatively clean TK crabs also varied with each metal, and was significantly lower than the conspecifics from $\mathrm{PC}, 3 \% \mathrm{Cu}, 56 \% \mathrm{~Pb}$, and $8 \% \mathrm{Zn}$. 


\section{Discussion}

Our results indicate that fiddler crabs from more contaminated areas have higher concentrations of metals and they depurate a significant amount of certain metals (lead). The proportions in which they store these metals (soft tissues/exoskeleton) varies with metal type.

We also discovered that the proportion of metals stored in the soft tissues and carapace does change between the intermolt and molt phases. Both populations of crabs shifted $\mathrm{Cu}$ and $\mathrm{Zn}$ from the carapace into the soft tissues prior to molting. This is similar to Engel (1987) who found that the distribution of $\mathrm{Cu}$ in the blue crab, Callinectes sapidus, changed prior to molt. Copper distributions in the lobster, Homarus gammarus, have also been shown to change just prior to molting with more copper being shifted into the soft tissues (Hagerman, 1983).

Previous studies indicate that molting as a mechanism for detoxification may vary depending upon the particular element and crustacean species. Keteles and Fleeger, (2001) found that molting in grass shrimp, Palaemonetes pugio, did not substantially reduce copper, zinc and cadmium levels, as they were reabsorbed along with Ca prior to ecdysis. In contrast, crabs from PC, the highly contaminated site, shifted a considerable amount of $\mathrm{Pb}$ from soft tissues to the exoskeleton prior to molt, thereby depurating a large amount of $\mathrm{Pb}$. TK shifted crabs did the opposite and shifted $\mathrm{Pb}$, as well as $\mathrm{Cu}$ and $\mathrm{Zn}$, from the carapace into the soft tissues. Even though the fiddler crabs from the cleaner environment shifted some $\mathrm{Pb}$ into their soft tissues prior to molting they were also able to depurate a substantial amount of this non essential element. 
Fiddler crabs can incorporate substantial amounts of lead into their carapace and eliminate them during molting, and the relative amount of depuration is greater in crabs from contaminated sites with higher body burdens. Molting in Uca pugnax appears to be a feasible mechanism for fiddler crabs to significantly reduce their overall body burden of lead.

The levels at which the crabs can depurate varies significantly with each metal. Large fractions of lead are eliminated along with the shed exuvium, while very little $\mathrm{Cu}$ and $\mathrm{Zn}$ are eliminated with the exoskeleton. Copper and zinc are essential metals while lead has no known biological function (Abel, 1998). Copper is part of hemocyanin, the blood pigment in decapod crustaceans and is instrumental in forming the new exoskeleton during ecdysis (Keteles and Fleeger, 2001). Zinc is a component of some enzymes, and can be effectively regulated in crustaceans and may be lost through excretion across the gills (Bryan, 1968; White and Rainbow, 1984).

It is uncertain how long this detoxification as a result of molting will last for crabs in the field. White and Rainbow (1984) demonstrated that for some crustaceans, metals can be absorbed from the surrounding water through the soft new cuticle if molting occurs in contaminated water. White and Rainbow (1986) found that although there was some loss of Cd (15\%) from the shrimp, Palaemon elegans, as a result of molting, the new soft cuticle readily took up additional $\mathrm{Cd}$ from the water, and the exuvia took up large amounts after being shed into water with high concentrations of $\mathrm{Cd}$. The metal-rich exuvium may also be consumed by the crab itself or other organisms within the estuary. If consumed by other organisms in the estuary it could facilitate trophic transfer. 


\section{Acknowledgements}

The authors would like to thank Dr. Peddrick Weis and Ted Proctor from the University of Medicine and Dentistry of New Jersey, Newark, for the use of their equipment and expertise in metals analysis. We would also like to thank the Rutgers University Marine Field Station, Tuckerton, NJ for funding support. 


\section{References}

Abel, P.D. 1998. Water Pollution Biology. Taylor \& Francis CRC Press, Bristol, PA.

Bertness, M.D. 1985. Fiddler crab regulation of Spartina alterniflora production on a New England salt marsh. Ecology, 66(3):1042-1055.

Bondgaard, M. and P. Bjerregaard. 2005. Association between cadmium and calcium uptake and distribution during the moult cycle of female shore crabs, Carcinus maenas: an in vivo study. Aquatic Toxicology, 71(1-2):17-28.

Brown, B.E. 1982. The form and function of metal-containing 'granules' in invertebrate tissues. Biological Reviews of the Cambridge Philosophical Society (London), 57:621-667.

Bryan, G. W. 1968. Concentrations of zinc and copper in the tissues of decapod crustaceans. Journal of Marine Biological Association of the United Kingdom, 48:303-321.

Callahan, P. and J. S. Weis. 1983. Methyl-mercury effects on regeneration and ecdysis in fiddler crabs (Uca pugilator, U. pugnax) after short-term and chronic preexposure. Archives of Environmental Contamination and Toxicology, 12:707714.

Carvalho, F.P. and S. Fowler. 1993. An experimental study on the bioaccumulation and turn over of polonium-210 and lead-210 in marine shrimp. Marine Ecology Progress Series, 102:125-133.

Crane, J. 1975. Fiddler Crabs of the World. Princeton: Princeton University Press, 736 pp.

DeFur, P.L., M. Crane, C.G. Ingersoll, and L.J. Tattersfield, editors. 1999. Endocrine disruption in invertebrates: Endocrinology, testing, and assessment. Workshop on Endocrine Disruption in Invertebrates: Endocrinology, Testing, and Assessment; 1998 Dec 12-15; Noordwijerhout, The Netherlands. Published by the Society of Environmental Toxicology and Chemistry (SETAC). 320 pp.

Elumalai, M., C. Antunes, and L. Guilhermino. 2004. Alterations of reproductive parameters in the crab Carcinus maenas after exposure to metals. Water, Air, and Soil Pollution, 160:245-258

Engel, D.W. 1987. Metal regulation and molting in the blue crab, Callinectes sapidus: copper, zinc, and metallothionein. Biological Bulletin, 172:69-82.

Gibbs, P.E. and G.W. Bryan. 2003. A study of strontium, magnesium, and calcium in the environment and exoskeleton of decapod crustaceans, with special reference to Uca burgersi on Barbuda, West Indies. Journal of Experimental Marine Biology and Ecology, 9(1):97-110. 
Greenaway, P. 1985. Calcium balance and moulting in the crustacea. Biological Reviews, 60:425-454.

Keteles, K. A. and J.W. Fleeger. 2001. The contribution of ecdysis to the fate of copper, zinc, and cadmium in grass shrimp, Palaemontes pugio Holthius. Marine Pollution Bulletin, 42(12):1397-1402.

Perez, M.H. and W.G. Wallace. 2004. Differences in prey capture in grass shrimp, Palaemonetes pugio, collected along an environmental impact gradient. Archives of Environmental Contamination and Toxicology, 46(1):81-89.

Raessler, M, Rothe, J. and I. Hilke. 2005. Accurate determination of $\mathrm{Cd}, \mathrm{Cr}, \mathrm{Cu}$ and $\mathrm{Ni}$ in woodlice and their skins-is moulting a means of detoxification? Science of the Total Environment, 337:83-90.

Reinsel, K.A. 2004. Impact of fiddler crab foraging and tidal inundation on an intertidal sandflat: season-dependent effect in one tidal cycle. Journal of Experimental Marine Biology and Ecology, 313:1-17.

Roesijadi, G. 1992. Metallothioneins in metal regulation and toxicity in aquatic animals. Aquatic Toxicology, 22:81-114.

Santiago Bass, C., S. Bhan, G. M. Smith and J. S. Weis 2001. Some factors affecting size distribution and density of grass shrimp (Palaemonetes pugio) populations in two New Jersey estuaries. Hydrobiologia 450:231-241.

Skinner, D.M. and D.E. Graham. 1972. Loss of limbs as a stimulus to ecdysis in Brachyura (true crabs). Biological Bulletin, 143:222-233.

Vernberg, F. J., Verberg, W. 1974. Multiple Environmental Factor Effects on Physiology and Behavior of the Fiddler Crab, Uca pugilator. In: Pollution and Physiology of Marine Organisms Eds. F.J. Vernberg and W .B. Vernberg, Academic Press, New York. 381-425.

Wallace, W.G., T.M. Hoexum Brouwer, M. Brouwer, and G. R. Lopez. 2000. Alteration in prey capture and induction of metallothioneins in grass shrimp fed cadmiumcontaminated prey. Environmental Toxicology and Chemistry, 19(4):962-971.

Weeks, J.M., P. S. Rainbow, and P.G. Moore. 1992. The loss, uptake and tissue distribution of copper and zinc during the moult cycle in an ecological series of talitrid Amphipods (Crustacea:Amphipoda). Hydrobiologia, 245:15-25. 
Weis, J.S. 1976. The effect of mercury, cadmium and lead salts on limb regeneration in the fiddler crab, Uca pugilator. Fishery Bulletin, 74(2):464-467.

Weis, J.S. 1980. The effect of zinc on regeneration in the fiddler crab, Uca pugilator, and its interactions with methylmercury and cadmium. Marine Environmental Research, 3:249-255.

Weis, J.S., A. Cristini, and K.R. Rao. 1992. Effects of pollutants on molting and regeneration in Crustacea. American Zoologist, 32:495-500.

Weis, J.S., P. Weis, G. Smith, T. Zhou, C. Santiago-Bass, C., 2001. Effects of contaminants on behavior: Biochemical mechanisms and ecological consequences. BioScience, 51:2092-17.

White, S. L. and P. S. Rainbow, 1984. Zinc flux in Palaemon elegans (Crustacea, Decapoda): molting, individual variation and tissue distribution. Marine Ecology Progress Series, 19(1-2):153-166.

White, S.L. and Rainbow, P. S. 1986. Accumulation of cadmium by Palaemon elegans (Crustacea: Decapoda). Marine Ecology Progress Series, 32:17-25. 
Fig. 1

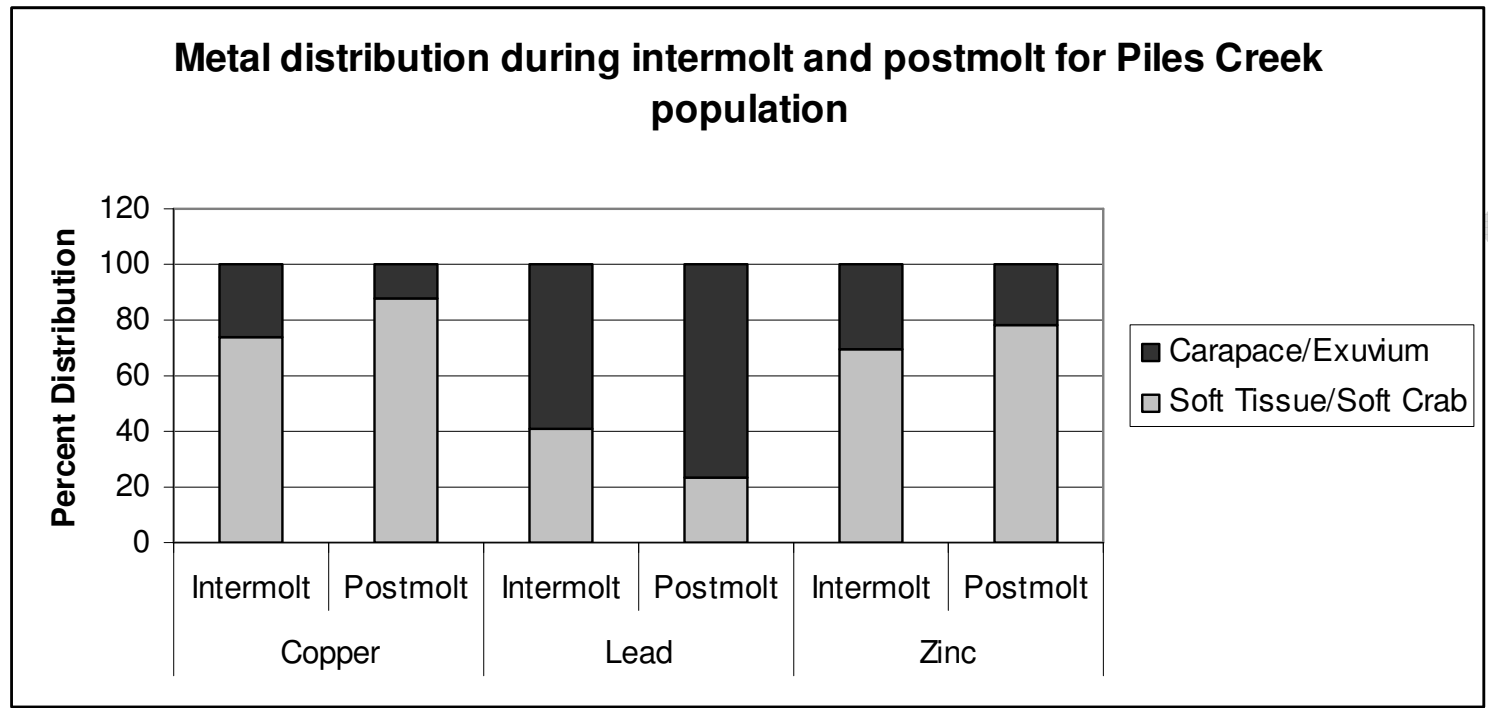

Figure 1. Metal distribution during the intermolt and postmolt for Piles Creek population. 


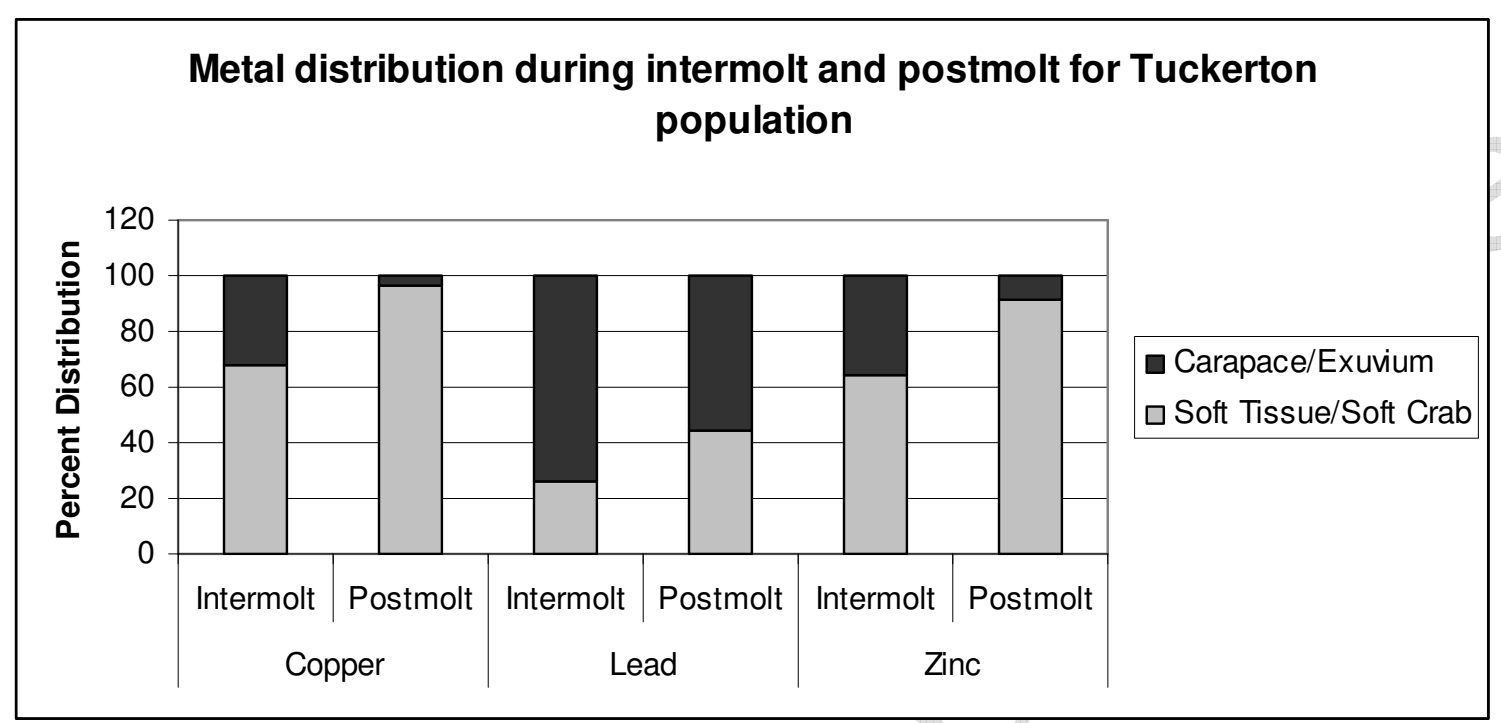

Figure 2. Metal distribution during the intermolt and postmolt for Tuckerton population. 
Table 1. Mean metal concentrations (ug/g) \pm SE and proportions of metal storage in tissue vs. carapace (ratios as a function of total body burden) in intermolt crabs from Piles Creek and Tuckerton. Asterisks indicate significantly higher concentrations when comparing soft tissues vs. carapace within the same population. $\mathrm{ST}=$ Soft Tissue $\mathrm{CP}=$ Carapace

\begin{tabular}{cccc|ccc} 
& Piles Creek & $\mathrm{n}=18$ & & Tuckerton & $\mathrm{n}=18$ & \\
\cline { 2 - 7 } Copper & $639.69 \pm 39.28 *$ & $152.71 \pm 11.29$ & 5.98 & $518.89 \pm 31.09 *$ & $136.66 \pm 4.54$ & 2.26 \\
Lead & $41.37 \pm 6.28$ & $41.28 \pm 4.50$ & 0.81 & $20.36 \pm 2.67$ & $27.03 \pm 1.54$ * & 0.39 \\
Zinc & $165.78 \pm 12.59 *$ & $46.58 \pm 2.46$ & 5.37 & $149.85 \pm 6.25 *$ & $46.64 \pm 2.28$ & 1.94 \\
\hline
\end{tabular}


Table 2. Mean metal concentrations (ug/g) \pm SE and proportions of metal storage in the soft crab vs. exuvium (ratios as a function of total body burden) in post-molt crabs from Piles Creek and Tuckerton. Asterisks indicate significantly higher concentrations when comparing soft tissues vs. exuvia within the same population. $\mathrm{SC}=$ Soft $\mathrm{Crab} \mathrm{EX}=$ Exuvium

\begin{tabular}{|c|c|c|c|c|c|c|}
\hline & Piles Creek & $n=25$ & & Tuckerton & $\mathrm{n}=20$ & \\
\hline & SC & $E X$ & Ratio & SC & EX & Ratio \\
\hline Copper & $306.46 \pm 18.07$ * & $78.53 \pm 6.48$ & 9.97 & $194.37 \pm 8.14$ * & $16.72 \pm 2.53$ & 46.44 \\
\hline Lead & $18.31 \pm 2.11$ & $129.81 \pm 9.81$ * & 0.33 & $11.46 \pm 0.64$ & $33.07 \pm 3.85$ * & 0.84 \\
\hline Zinc & $133.30 \pm 10.75$ * & $79.63 \pm 8.48$ & 4.39 & $108.75 \pm 2.28$ * & $25.63 \pm 1.90$ & 14.47 \\
\hline
\end{tabular}

